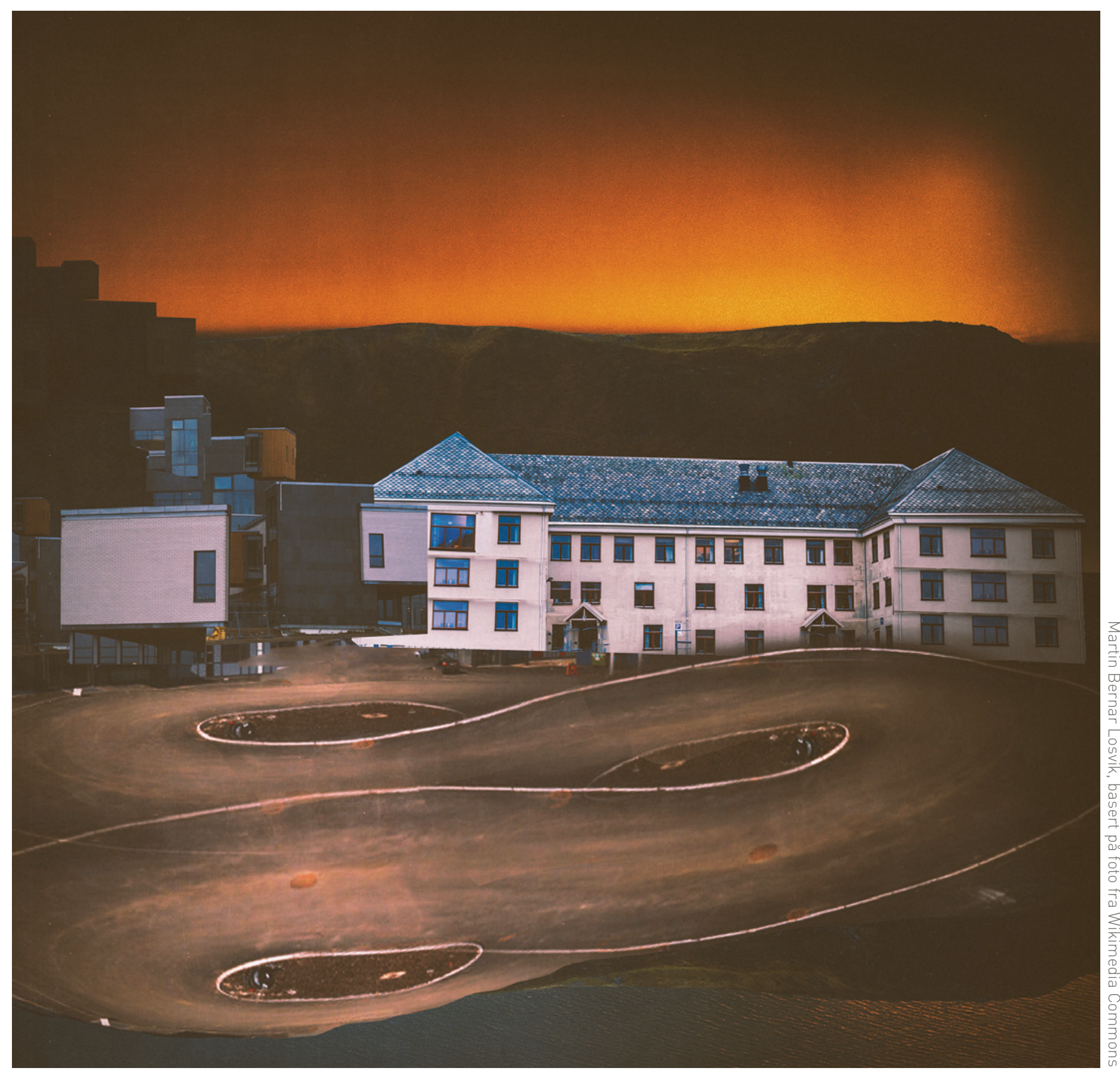

\title{
Stokmarknes sykehus
}

I slutten av mai 2014 ble et nytt og moderne sykehus tatt i bruk på Stokmarknes i Vesterålen. Det er lokal-
sykehus for omtrent 30000 innbyggere og har blant annet akuttberedskap, interkommunal legevakt, indre-
medisin og kirurgi, fødeavdeling og medisinske servicefunksjoner. 